\title{
CORRELATION BETWEEN THE SHORT SEA SHIPPING CAPABILITY (POTENTIAL) OF A PORT AND PORT MACHINERY FLEXIBILITY
}

\author{
Deda Đelović ${ }^{1}$ \\ ${ }^{1}$ Port of Bar, Montenegro \\ Received 3 May 2015; accepted 17 August 2015
}

\begin{abstract}
The promotion of environmentally friendly modes of transport, in particular Short Sea Shipping, and their effective integration in multimodal transport chains and networks is one from the group of central objectives of the European Union's transport policy. According to results of different relevant researches available to the author, to the group of problems which still hamper Short Sea Shipping development belongs lack of flexibility in ports. Port machinery flexibility, in general, is one of the factors with decisive influence on port flexibility. After some general considerations of the Short Sea Shipping concept, parameters which enable measuring Short Sea Shipping capability (potential) of a port, from the aspect of port machinery, are identified. Interdependences between port machinery flexibility and Short Sea Shipping capability (potential) of a port (using the Port of Bar as an object of analysis) are taken into detailed consideration in this paper, too. By the results of analyses presented in the paper is confirmed existence of correlation between the Short Sea Shipping capability (potential) of a port and port machinery flexibility: to a higher level of the Short Sea Shipping capability (potential) of a port corresponds a higher level of port machinery flexibility.
\end{abstract}

Keywords: short sea shipping, port machinery flexibility.

\section{Introduction}

Short Sea Shipping means the movement of cargo and passengers by sea between ports situated in geographical Europe or between those ports and ports situated in non European countries having a coastline on the enclosed seas bordering Europe. Short sea shipping includes domestic and international maritime transport, including feeder services, along the coast and to and from the islands, rivers and lakes. The concept of short sea shipping also extends to maritime transport between the Member States of the Union and Norway and Iceland and other States on the Baltic Sea, the Black
Sea and the Mediterranean (European Commission, The Development of Short Sea Shipping in Europe, Short Sea Promotion Centre).

Short sea shipping is not restricted to short distances. It refers to coastal transportation linking the European ports with adjacent countries (including the entire Mediterranean Basin: shipping from Gothenburg to Istanbul is thus considered to be short sea shipping). Short sea shipping is divided into very different types of flows using different techniques: transportation of bulk cargo (particularly for crude and refined petroleum products) and general

${ }^{1}$ Corresponding author: deda.djelovic@lukabar.me 
cargo split into two main transportation techniques: Lo-Lo and Ro-Ro (Short Sea Shipping in Europe).

Short sea shipping is understood to cover maritime transport services which do not involve an ocean crossing (Papadimitriou, 2011; Styhre et al., 2014; University of Michigan).

Short sea shipping is a logistics concept performing the sea leg of door-to-door freight transport of containers, trailers, general cargo and bulk within Europe and with countries geographically close to Europe (European Commission).

When considering where expanded short-sea shipping operations may have the highest probability of success, it is important to look at several factors, including (Cambridge Systematics, Inc.):

- Modal Access - Potential short-sea ports must have effective, efficient access to other modal networks (highway and rail).

- Berth Availability - Short-sea operations calling at some major deepwater seaports often do not receive a high priority for berthing, particularly in comparison to large, ocean-going containerships. Ports that can regularly offer berths may be better able to attract short-sea traffic. This is a major advantage of using underutilized ports as magnets for short-sea shipping.

- Crane/Stevedore Cargo Handling Capacity - Potential short-sea ports must have the ability to load and offload ships quickly and efficiently. This also is an important component, as efficient loading and offloading will help short-sea shipping operations match the cost, speed, and reliability characteristics of competing modes. Those ports wishing to enhance their abilities to attract short-sea services international or domestic - must ensure that adequate and appropriate cargo handling capacity exists.

- Access to Capital - Finally, access to capital is a critical element, as ports must be able to raise capital quickly in order to make infrastructure improvements to retain existing customers and attract new ones.

Results of relevant researches done confirm that existence of adequate port machinery handling capacity belongs to the group of decisive influential factors on short sea shipping operation success.

The most important opportunities, offered by the short sea shipping, can be summarized as follow: lower costs per shippers, less road accidents, lower road congestion, potential lower emissions, lower external costs, lower entry barriers into the market, lower rail/ road maintenance costs, etc. (Styhre et al., 2014).

Short sea shipping has environmental and economic benefits over traditional modes of truck and rail transportation (University of Michigan).

A fundamental step in understanding shortsea shipping and its potential to become a viable component of an intermodal transportation system is to develop a detailed comprehension of the types of commodities that could be served by short-sea operations, along with the origins and destinations that could be linked. It is also important to understand the existing market for short-sea shipping, and to determine the obstacles that 
prevent those services from being utilized to their full potentials (Cambridge Systematics, Inc.).

However, a review of overall transport policies in Europe shows that the current view of short sea shipping as an alternative to road transport is probably too narrow to exploit the full potential of this mode of transport as a means of achieving the objectives and does not take sufficient account of the way in which transport market structures in Europe have developed (Report adopted by the ECMT Ministers of Transport, 2011).

Development of short sea shipping requires in parallel and an increase of port efficiency and the improvements in reliability and safety (Papadimitriou, 2011).

With respect to technical aspects and handling procedures, port performances have to be improved as stated by researchers and organisations/institutions involved in this field of activities. Obviously short sea shipping is competitive if time spent in ports can be significantly reduced. A great number of all ports do not dispose of upto-date handling equipment. Respective movements would allow shorter turnaround times in ports and hence reduce travel time and transport cost (Zachcial, 2011).

Paixao Casaca and Marlow (2005) defined five short sea shipping market segments: box-shaped ships, container feeder ships, ferries, dry bulk and tankers and sea-river ships and point out that strong technical capabilities in terms of handling equipment, vehicles and storing conditions belong to the group of service attributes. Results of these researches are an important base for defining demands (technological, operational, etc.) which is a port (as a link of Short Sea Shipping transport chain) faced with.

Ports - as interfaces - are particularly important for the integration of short sea shipping with combined transport modes. For combined transport, ports are major transhipment points at which road, rail and river and sea traffic converge (Report adopted by the ECMT Ministers of Transport, 2011).

Results of researches confirm that turnaround delays in ports are mostly created by lack of suitable infrastructure, lack of suitable land connections and inefficiencies in handling the goods (e.g. handling speeds vary considerably between ports) (The Development of Short Sea Shipping in Europe).

Sanchez and Wilmsmeier (2005) proposed key influential factors on increased short sea shipping potential, focusing the discussion and eventually enhance understanding concerning the short sea shipping concept as an important milestone in future transport development.

Based on the analyses done in De la Lastra (2004), several factors which limit short sea shipping full development are recognized: insufficient integration in the intermodal chain, administrative complexity, lack of efficiency, flexibility and transparency in ports; etc.

By the considerations given in the available literature is directly recognized importance of the port machinery for the short sea shipping capability (potential) of a port, but it is an obvious lack of deeper researches of correlations between mentioned short sea 
shipping capability (potential) of a port and parameters related to the port machinery. Due to the facts that lack of flexibility in ports was recognized as one from the group of factors which limit short sea shipping full development (De la Lastra, 2004) and that the level of port machinery flexibility belongs to the group of factors with decisive influence on overall level of port flexibility, it was decided to perform (using Port of Bar as an object of analysis) a research of correlations between the short sea shipping capability (potential) of a port and port machinery flexibility.

\section{Hypothesis and Objectives of the Research}

Based on the results of considerations done in (Delovic, 2014), from the operational and technological points of view, port machinery flexibility has two main compoments: positional flexibility and technological flexibility.

Positional flexibility considers that port machinery performances make possible its usage on different position within port (terminal) area and the technologicalflexibility means that exploitation characteristics of the machinery can match very wide range of technological requirements generated during the cargo handling process. Both flexibility components are determined by numerous factors of different character and intensity of influence.

Starting hypothesis of the research presented in this paper is: higher level of the port machninery flexbility means and increased short sea shipping capability (potential) of a port.

Key objectives of the research are: to identify parameters for measuring short sea shipping capability (potential) of a port, from the aspect of port machinery; to recognize character of influence of increased port machinery flexibility (through simulation of effects of introducing a flexible port crane) on short sea shipping capability (potential) of a port; to establish bases for further researches in this domain.

\section{Description of the Port of Bar as Object of an Analysis}

Using principle elements of the WORKPORT model structure (Beresdorf et al., 2004), in the Table 1 are systematized basic performances of the Port of Bar (Documentation of the Port of Bar, 2014). 
Table 1

Basic Performances of the Port of Bar

\begin{tabular}{|c|c|}
\hline Year & 2014 \\
\hline $\begin{array}{l}\text { OWNERSHIP/ } \\
\text { MANAGEMENT } \\
\text { MODEL }\end{array}$ & $\begin{array}{l}\text { The Port of Bar is a landlord port; it is functioning based on the Montenegrin Law on } \\
\text { ports; at the port area are operating two main Port Terminal Operators: Port of Bar } \\
\text { H. Co. (a share holding company, where majority of shares - 54\% - are owned by the } \\
\text { Government of Montengro) and the Container and General Cargo Terminal, where } \\
\text { major part of shares - } 62 \% \text { - are owned by the Turkish Company Global Ports; } \\
\text { The first Port Terminal Operator, Port of Bar H. Co. is managing following specialized } \\
\text { terminals: Terminal for dry bulk cargoes, Terminal for liquid cargoes, Terminal for grain, } \\
\text { Ro-Ro and Passenger terminal; } \\
\text { The second Port Terminal Operator, General and Container Cargo Terminal is managing } \\
\text { Terminal for general cargoes, Terminal for containers and Terminal for sawn timber; }\end{array}$ \\
\hline $\begin{array}{l}\text { THROUGHPUT } \\
\text { STRUCTURE }\end{array}$ & $\begin{array}{l}\text { Main cargo groups which are handled in The Port of Bar are: liquid bulk cargoes (LB); } \\
\text { dry bulk cargoes (DB); general Lo-Lo cargoes (G-Lo-Lo); Containers Lo-Lo (C); } \\
\text { General Ro-Ro cargoes (G-Ro-Ro); }\end{array}$ \\
\hline $\begin{array}{l}\text { CARGO HANDLING } \\
\text { TECHNOLOGIES }\end{array}$ & $\begin{array}{l}\text { Handling operations with general cargoes are mechanized, as well as handling operations } \\
\text { with dry bulk cargoes; Operations with liquid cargoes are highly mechanized and } \\
\text { automatized; }\end{array}$ \\
\hline $\begin{array}{l}\text { INFORMATION } \\
\text { SYSTEM }\end{array}$ & $\begin{array}{l}\text { Automatized integral information system which covers all business activities; Internet; } \\
\text { Intranet; EDI system is implemented in process of distribution of Quality system } \\
\text { documentation; }\end{array}$ \\
\hline $\begin{array}{l}\text { WORK FORCE/ } \\
\text { WORK } \\
\text { ORGANIZATION/ } \\
\text { EMPLOYMENT } \\
\text { RELATIONS/ } \\
\text { LABOUR } \\
\text { RELATIONS } \\
\end{array}$ & $\begin{array}{l}\text { Hierarchical work organization; Degree of work force specialization is increased; } \\
\text { Greater emphasis on qulity aspect of provided services; Internationally certified Quality } \\
\text { Management System, modeled according to standard ISO 9001: 2008, exists; }\end{array}$ \\
\hline $\begin{array}{l}\text { PORT FUNCTION/ } \\
\text { PORT } \\
\text { DEVELOPMENT }\end{array}$ & $\begin{array}{l}\text { Handling operations are in the focus; The Port of Bar, at complete territory (expcept a } \\
\text { part of Ro-Ro and Passenger terminal), is a Free Zone; }\end{array}$ \\
\hline $\begin{array}{l}\text { HEALTH AND } \\
\text { SAFETY ASPECT } \\
\text { OF WORKING } \\
\text { ENVIRONMENT }\end{array}$ & $\begin{array}{l}\text { Improved training in safety awareness; Decreasing accidents rate and physical health } \\
\text { problems; Health and safety policy exists; } \\
\text { Complete port territory is under video surveillance; ISPS Code is fully implemented } \\
\text { since July 1st, 2004; }\end{array}$ \\
\hline $\begin{array}{l}\text { ENVIRONMENTAL } \\
\text { PROTECTION }\end{array}$ & $\begin{array}{l}\text { Process of introducing certified Environmental Management System is taking place; } \\
\text { Analyses of environmental aspects are obligatory part of all projects realized within the } \\
\text { port area; }\end{array}$ \\
\hline
\end{tabular}

More detailed operational features of the Port of Bar (whole area), with special focus on the port machinery installed at the operational quay (berths), are presented in the Table 2. 
Table 2

Operational Features of the Port of Bar - Existing Situation

\begin{tabular}{|c|c|c|c|c|c|c|c|c|c|c|}
\hline \multirow[t]{2}{*}{ Berth } & \multirow[t]{2}{*}{$\begin{array}{l}\text { Water } \\
\text { depth } \\
(\mathrm{m})\end{array}$} & \multicolumn{2}{|c|}{$\begin{array}{l}\text { Availability } \\
\text { of the } \\
\text { shore port } \\
\text { machinery }\end{array}$} & \multirow[t]{2}{*}{$\begin{array}{l}\text { Type of the port } \\
\text { machinery }\end{array}$} & \multicolumn{5}{|c|}{$\begin{array}{l}\text { Cargo types which can be handled } \\
\text { (LB - Liquid bulks; DB - Dry } \\
\text { bulks; G - Lo-Lo - General Lo-Lo; } \\
\text { C - containers Lo-Lo; G - Ro-Ro - } \\
\text { General Ro-Ro; }\end{array}$} & \multirow[t]{2}{*}{$\begin{array}{l}\text { Cargo handling operations } \\
\text { (possible) }\end{array}$} \\
\hline & & Yes & No & & LB & DB & $\begin{array}{l}\text { G } \\
\text { Lo- } \\
\text { Lo }\end{array}$ & $\mathrm{C}$ & $\begin{array}{l}\text { G } \\
\text { Ro- } \\
\text { Ro }\end{array}$ & \\
\hline (1) & (2) & $(3)-1$ & $(3)-2$ & (4) & $(5)-1$ & $(5)-2$ & $(5)-3$ & $(5)-4$ & $(5)-5$ & (6) \\
\hline NPV & 13,0 & & * & - & * & & & & & $\begin{array}{l}\text { Liquid bulks : Ship to } \\
\text { reservoir (1); }\end{array}$ \\
\hline $\mathrm{SO} 3$ & 7,5 & & * & - & * & & & & & $\begin{array}{l}\text { Liquid bulks : Ship to } \\
\text { reservoir (1); }\end{array}$ \\
\hline $\mathrm{SO} 2$ & 7,0 & & * & - & * & & & & & $\begin{array}{l}\text { Liquid bulks : Wagon to } \\
\text { ship (1); }\end{array}$ \\
\hline SO1 & 6,5 & & * & - & & * & & & & Dry bulks: Ship to silo (1); \\
\hline 03 & 14,0 & * & & $\begin{array}{l}\text { Ship to shore } \\
\text { gantry cranes ( } 3 \\
\text { pcs.), SWL } 12 \\
\text { t, rail mounted, } \\
\text { movable by all } \\
\text { three berths; }\end{array}$ & * & * & * & & & $\begin{array}{l}\text { Liquid bulks: Ship to } \\
\text { reservoir (1); } \\
\text { Dry bulks: Ship to shore/ } \\
\text { truck/ wagon (and vice } \\
\text { versa) (3); } \\
\text { General Lo-Lo: ship to } \\
\text { shore/truck/ wagon (and } \\
\text { vice versa) (3); }\end{array}$ \\
\hline 02 & 14,0 & * & & & & * & * & & & Dry bulks: Ship to shore/ \\
\hline 01 & 14,0 & * & & & & * & * & & & $\begin{array}{l}\text { truck/ wagon } \\
\text { (and vice versa); ship to } \\
\text { silo (and vice versa) (4); } \\
\text { General Lo-Lo: ship to } \\
\text { shore/truck/ wagon } \\
\text { (and vice versa) (3); }\end{array}$ \\
\hline 11 & 12,5 & * & & $\begin{array}{l}\text { Container crane, } \\
\text { SWL } 40 \text { t, rail } \\
\text { mounted; }\end{array}$ & & & * & * & * & $\begin{array}{l}\text { General Lo-Lo: ship to } \\
\text { shore/truck/ wagon } \\
\text { (and vice versa) ( } 3 \text { ); } \\
\text { Containers Lo-Lo: ship to } \\
\text { shore/ truck/ wagon (and } \\
\text { vice versa) (3); } \\
\text { General Ro-Ro: ship to } \\
\text { shore (and vice versa) (1); }\end{array}$ \\
\hline 12 & 12,5 & * & & $\begin{array}{l}\text { Portal crane, } \\
\text { SWL } 32 \text { t, rail } \\
\text { mounted; }\end{array}$ & & * & * & & & $\begin{array}{l}\text { Dry bulks: Ship to truck/ } \\
\text { wagon (and vice versa) (2); } \\
\text { General Lo-Lo: ship to } \\
\text { shore/truck/ wagon (and } \\
\text { vice versa) (3); }\end{array}$ \\
\hline
\end{tabular}




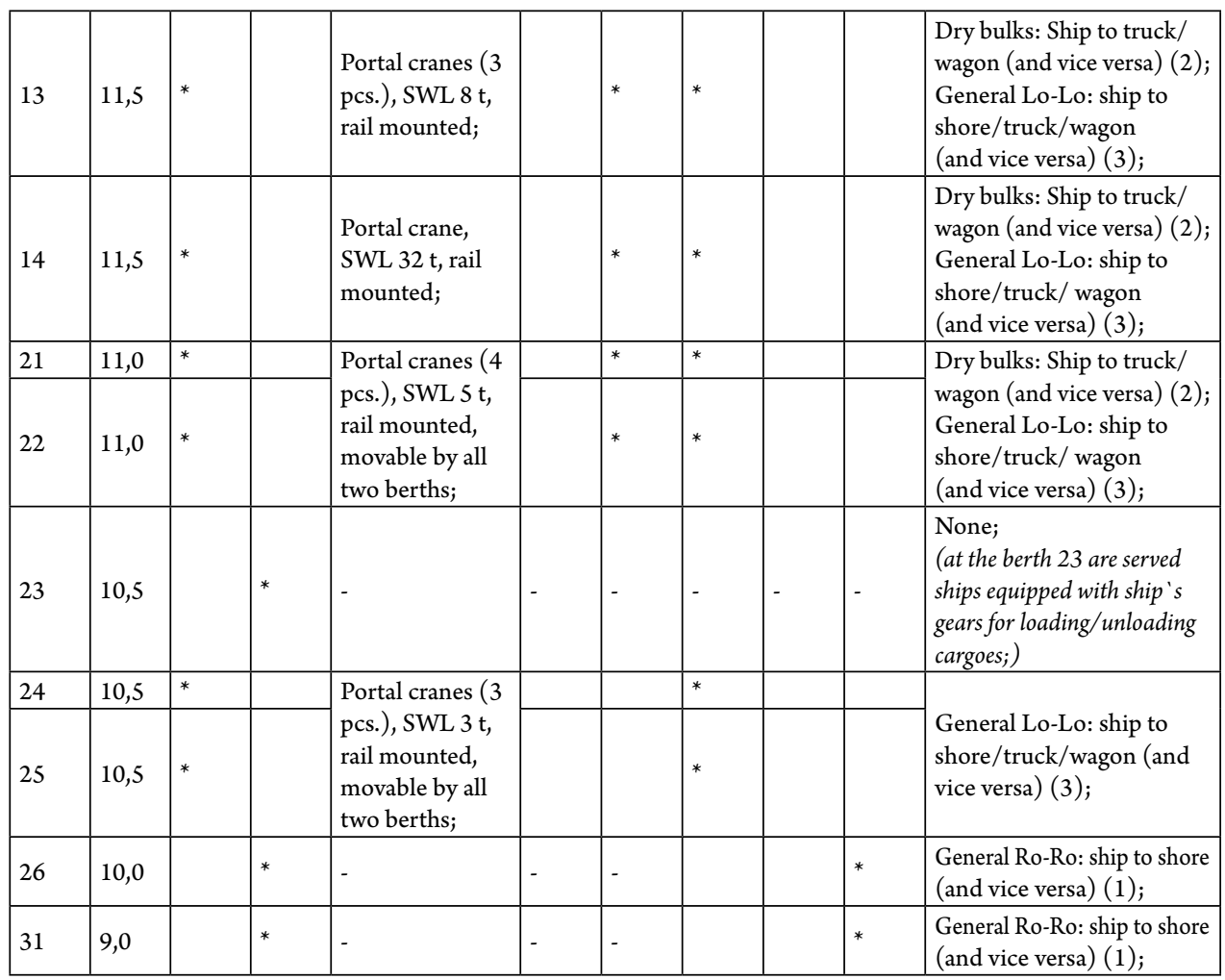

Additional remarks: all berths are accessible by road; majority of berths (except berths NPV, SO3 and 31) are accessible by railway; allowed pressure on quay construction is $4 \mathrm{t} / \mathrm{m}^{2}$; in the brackets (last right column) are given numbers of possible handling operations respecting available shore port machinery; "SWL" - Safe Working Load.

\section{Identification of Parameters for Measuring Short Sea Shipping Capability (Potential) of a Port}

Short sea shipping capability (potential) of a port, from the aspect of available shore port machinery, can be measured by following group of parameters:
- availability of port machinery (by berths), $A$; two statuses are possible: " $\mathrm{Y}$ " - port machinery is available at a berth; "N" - port machinery is not available at a berth;

- number of cargo types which can be handled (by berths), $N_{c t}$; parameter $N_{c t}$ takes values from 1 to 5 , depending on number of different cargo types which can be handled at a berth (DB - Dry bulks; LB - Liquid bulks; G-Lo-LoGeneral cargoes Lo-Lo; C - containers Lo-Lo; G-Ro-Ro-General cargoes RoRo;);

- number of handling operations which can be realized (by berths), $N_{o}$; this parameter is a sum of possible handling 
operations with all types of cargoes which can be handled at a berth; directions "vice versa" are not counted as a specific handling operation;

- number of gangs which can be allocated at a berth/ship, $N_{g}$; values of this parameter are equal to the number of available items of port machinery at a berth.

Based on the data systematized in Table 2, values of previously identified parameters related to the Port of Bar can be defined (Table 3).

\section{Table 3}

Values of Parameters which Determine the Port of Bar Short Sea Shipping Capability (Potential), from the Aspect of Available Shore Port Machinery

\begin{tabular}{|c|c|c|c|c|c|c|c|c|c|c|c|c|c|c|c|c|c|c|}
\hline Berth & NPV & SO3 & SO2 & SO1 & 03 & 02 & 01 & 11 & 12 & 13 & 14 & 21 & 22 & 23 & 24 & 25 & 26 & 31 \\
\hline $\mathrm{A}$ & $\mathrm{N}$ & $\mathrm{N}$ & $\mathrm{N}$ & $\mathrm{N}$ & $\mathrm{Y}$ & $\mathrm{Y}$ & $\mathrm{Y}$ & $\mathrm{Y}$ & $\mathrm{Y}$ & $\mathrm{Y}$ & $\mathrm{Y}$ & $\mathrm{Y}$ & $\mathrm{Y}$ & $\mathrm{N}$ & $\mathrm{Y}$ & $\mathrm{Y}$ & $\mathrm{N}$ & $\mathrm{N}$ \\
\hline $\mathrm{N}_{\mathrm{ct}}$ & 1 & 1 & 1 & 1 & 3 & 2 & 2 & 3 & 2 & 2 & 2 & 2 & 2 & 0 & 1 & 1 & 1 & 1 \\
\hline $\mathrm{N}_{\mathrm{o}}$ & 1 & 1 & 1 & 1 & 7 & 7 & 7 & 7 & 5 & 5 & 5 & 5 & 5 & 0 & 3 & 3 & 1 & 1 \\
\hline $\mathrm{N}_{\mathrm{g}}$ & 0 & 0 & 0 & 0 & 3 & 3 & 3 & 1 & 1 & 3 & 1 & 4 & 4 & 0 & 3 & 3 & 0 & 0 \\
\hline
\end{tabular}

Remark: "Y" - port machinery is available at berth; "N" - port machinery is not available at berth; „vice versa” directions from Table 2 (last right column) are not counted as specific operations.

Important bases of further considerations are and following analyses results:

- $\quad 12$ out of $18(67 \%)$ analyzed berths are equipped with shore port machinery;

- 6 out of 18 (33\%) analyzed berths are not equipped with shore port machinery;

- Port machinery is rail mounted and its SWL (Safe Working Load) ranges from $3 \mathrm{t}$ to $40 \mathrm{t}$;

- Installed shore port machinery has limited positional flexibility (only alongside berths where it is installed);

- Installed shore port machinery has limited technological flexibility; e.g. shore gantry cranes, installed at berths 01, 02 and 03, can be used for handling operations with dry bulk cargoes and a group of general (Lo-Lo) cargoes, but not and for handling operations with containers; etc.;

- Berth SO2 is equipped for handling operations with acetic acid (fixed installation) on the direction wagon to ship;

- At the berth SO1 are done unloading operations (from ships) with cement in bulk, using pneumatic system;

- Berths NPV, SO3 and 03 are equipped with installations for unloading liquid cargoes (from ships).

\section{Basic Directions of Improving Values of Parameters which Characterize Short Sea Shipping Capability (Potential)}

Taking into account results of previous analyses, it can be concluded that one of the principal directions of improving values of all defined parameters which characterize short sea shipping capability (potential) of the Port of Bar (a port in general) is introducing port machinery with high (optimal) level of flexibility (positional and technological). 


\section{Selecting Port Machinery with High (Optimal) Level of Flexibility}

The complex decision on which port machinery to select must be based on a broad range of factors. Some of the many factors (group of factors) that have to be taken into account in evaluating port machinery investment decisions are as follows (based on: Dobner and Rijsenbrij, 1999; Roach, 1987): port development factors; port machinery costs; port machinery maintenance; operating factors; manning requirements; berths utilization; character of existing and expected customers demands; limitation generated by port infrastructure objects; available port machinery utilization; utilization rate of existing port capacity; expected growth in overall throughput; etc.

This paper is not dealing with the port machinery selection, a crucially important process in the domain of port management, but in order to establish bases for recognizing correlations between the level of the port machinery flexibility and short sea shipping capability (potential) of a port, further analyses phases will take into account results of previous considerations referred on the port machinery flexibility, done by the author, where mobile harbour crane is recognized as a very good example of the flexible port machinery.

As described by Terex Corporate, a mobile harbour crane consists of a travelling device with rubber-tired wheels for travelling freely on harbour areas, outrigger and a crane unit to load and unload cargo onto or from a ship. The travelling device of the crane consists mainly of a frame for travelling, an outrigger device, a steering device and an operator's cab. Rubber-tired wheels are used when the crane travels, and an outrigger is used to support the crane unit during cargo handling operations. The crane unit consists of a slewing device to swing around the crane unit, a luffing device to raise the jib and a hoisting device to lift cargo. Cargo handling operation is performed by the three different actions of the crane: slewing, luffing and hoisting.

Using mobile harbor cranes in a port is fully justified from different aspects. Its mobility (positional flexibility) and capability to be used in different handling operations (technological flexibility) are bases for achieving high utilization rates, especially in situation characterized by intensive variations in a port throughput structure (intensive variations of customers' demands). Mobile harbor cranes can be used on various berths within the port area, at different terminals etc. In other words, "a mobile harbor crane is going to the cargo" and not "waiting for cargo" (as classic shore cranes normally do) (Dundovic, 2005). In addition, possibilities to change cranes lifting accessories (replacing a hook with a grab, etc.) in a shortest possible period of time are further advantages of these cranes.

Lifting and shifting cargoes are done in accordance with the mobile harbor crane load chart. Mobile harbor cranes are designed to work in different climate zones and there are no important specific elements related to local conditions. As well, there are no required prior civil construction (infrastructure) works (installing rails, etc.).

Exploitation of the mobile harbor cranes is connected and with two important groups of limitations while a mobile harbor crane is under operation: limitations related on the area where a crane is positioned (port transport means, trucks and wagons can not 
have optimal transport route through the location where a mobile crane is positioned; difficulties in moving crane from one position to another in case of existence of any kind of physical obstacles;) and limitations related to the allowed pressure on the quay construction. But, in the process of port machinery selection both limitation groups have to be taken into detailed consideration.

\section{An Analysis of Principal Effects of} Introducing a Mobile Harbour Crane on Parameters which Characterize Short Sea Shipping Capability (Potential) of a Port

An analysis (a simulation) of effects of introducing a mobile harbour crane (with adequate performances - in accordance with limitations existing in the Port of Bar) on parameters which characterize short sea shipping capability (potential) of the Port of Bar is conducted. Related results are shown with the Table 4, where principal effects of introducing a mobile harbour crane (with optimal positional and technological flexibility) on increasing short sea shipping capability (potential) of the Port of Bar, by analyzed berths, are systematized (shadowed text). Presented data take into account characteristics of existing infrastructure in the related parts of the port area (approaching roads, existence of railway to berths, availability of open storage area, etc.).

Table 4

Principal Effects of Introducing a Mobile Harbour Crane (MHC) by Berths

\begin{tabular}{|c|c|c|c|c|c|c|c|c|c|c|}
\hline \multirow[t]{2}{*}{ Berth } & \multirow[t]{2}{*}{$\begin{array}{l}\text { Water } \\
\text { depth } \\
\text { (m) }\end{array}$} & \multicolumn{2}{|c|}{$\begin{array}{l}\text { Availability } \\
\text { of the } \\
\text { shore port } \\
\text { machinery }\end{array}$} & \multirow[t]{2}{*}{$\begin{array}{l}\text { Type of } \\
\text { the port } \\
\text { machinery }\end{array}$} & \multicolumn{5}{|c|}{$\begin{array}{l}\text { Cargo types which can be handled } \\
\text { (LB - Liquid bulks; DB - Dry } \\
\text { bulks; G - Lo-Lo - General Lo-Lo; } \\
\text { C - containers Lo-Lo; G - Ro-Ro - } \\
\text { General Ro-Ro; }\end{array}$} & \multirow[t]{2}{*}{$\begin{array}{l}\text { Cargo handling operations } \\
\text { (possible) }\end{array}$} \\
\hline & & Yes & No & & LB & DB & $\begin{array}{l}\text { G } \\
\text { Lo-Lo }\end{array}$ & $\mathrm{C}$ & $\begin{array}{l}\text { G } \\
\text { Ro-Ro } \\
\end{array}$ & \\
\hline (1) & (2) & (3) -1 & $(3)-2$ & (4) & $(5)-1$ & $(5)-2$ & $(5)-3$ & $(5)-4$ & $(5)-5$ & (6) \\
\hline NPV & 13,0 & & * & - & * & & & & & Liquid bulks: Ship to reservoir (1); \\
\hline $\mathrm{SO} 3$ & 7,5 & & * & - & * & & & & & Liquid bulks: Ship to reservoir (1); \\
\hline $\mathrm{SO} 2$ & 7,0 & & * & - & * & & & & & Liquid bulks: Wagon to ship (1); \\
\hline SO1 & 6,5 & & * & - & & * & & & & Dry bulks: Ship to silo (1); \\
\hline
\end{tabular}




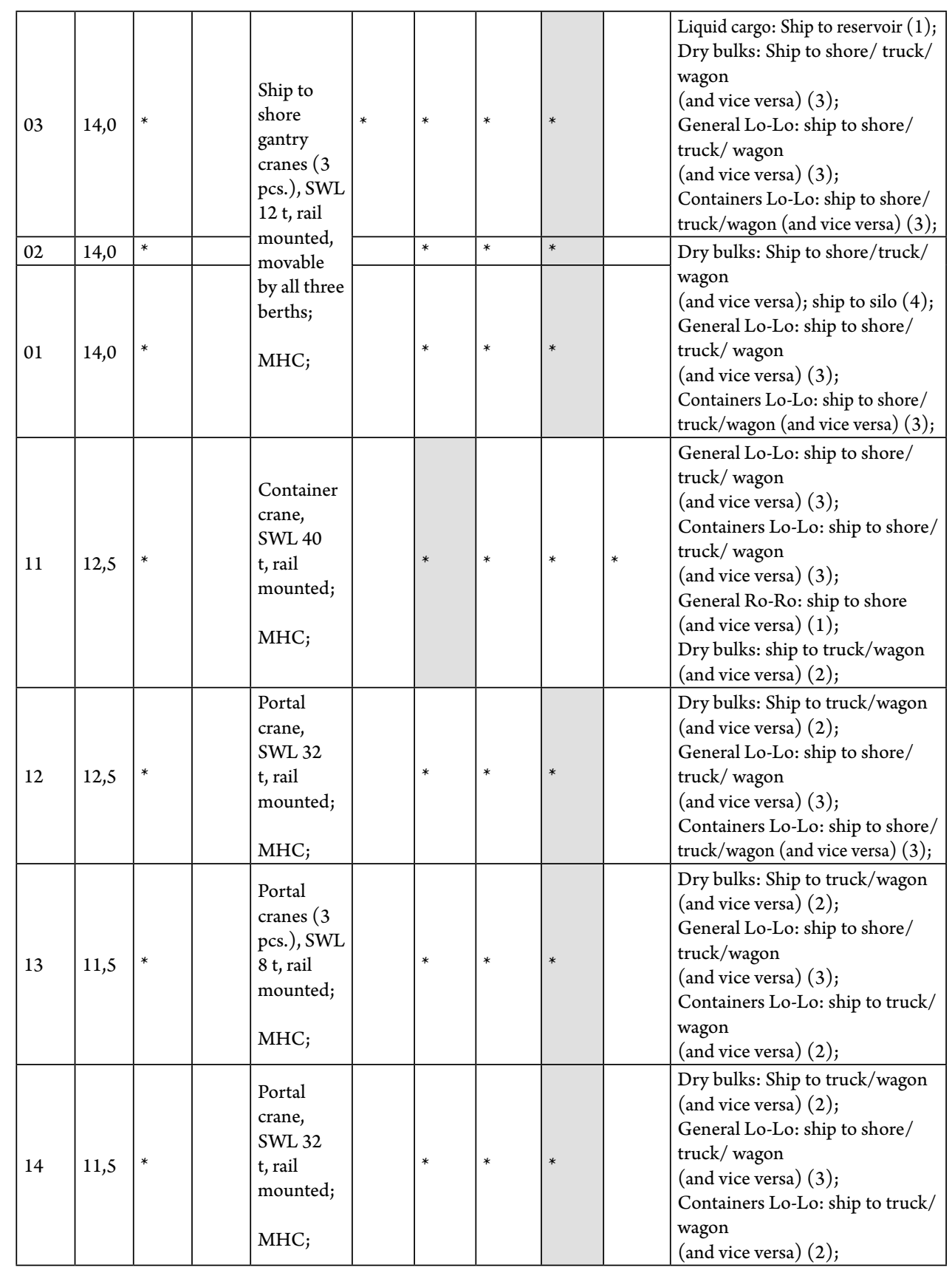




\begin{tabular}{|c|c|c|c|c|c|c|c|c|}
\hline 21 & 11,0 & * & \multirow[b]{2}{*}{$\begin{array}{l}\text { Portal } \\
\text { cranes }(4 \\
\text { pcs.), SWL } \\
5 \mathrm{t} \text {, rail } \\
\text { mounted, } \\
\text { movable } \\
\text { by all two } \\
\text { berths; } \\
\text { MHC; }\end{array}$} & * & * & * & & \multirow[b]{2}{*}{$\begin{array}{l}\text { Dry bulks: Ship to truck/wagon } \\
\text { (and vice versa) (2); } \\
\text { General Lo-Lo: ship to shore/ } \\
\text { truck/ wagon } \\
\text { (and vice versa) (3); } \\
\text { Containers Lo-Lo: ship to truck/ } \\
\text { wagon } \\
\text { (and vice versa) (2); }\end{array}$} \\
\hline 22 & 11,0 & * & & * & * & * & & \\
\hline 23 & 10,5 & * & MHC; & * & * & * & & $\begin{array}{l}\text { None; } \\
\text { (at the berth } 23 \text { are served ships } \\
\text { equipped with ship's gears for } \\
\text { loading/unloading cargoes;) } \\
\text { Dry bulks: Ship to truck/wagon } \\
\text { (and vice versa) (2); } \\
\text { General Lo-Lo: ship to shore/ } \\
\text { truck/ wagon } \\
\text { (and vice versa) (3); } \\
\text { Containers Lo-Lo: ship to truck/ } \\
\text { wagon } \\
\text { (and vice versa) (2); }\end{array}$ \\
\hline 24 & 10,5 & * & \multirow{2}{*}{$\begin{array}{l}\text { Portal } \\
\text { cranes (3 } \\
\text { pcs.), SWL } \\
3 \mathrm{t} \text {, rail } \\
\text { mounted, } \\
\text { movable } \\
\text { by all two } \\
\text { berths; } \\
\text { MHC; }\end{array}$} & * & * & * & & \multirow{2}{*}{$\begin{array}{l}\text { General Lo-Lo: ship to shore/ } \\
\text { truck/wagon } \\
\text { (and vice versa) (3); } \\
\text { Dry bulks: Ship to truck/wagon } \\
\text { (and vice versa) (2); } \\
\text { Containers Lo-Lo: ship to truck/ } \\
\text { wagon } \\
\text { (and vice versa) (2); }\end{array}$} \\
\hline 25 & 10,5 & * & & * & * & * & & \\
\hline 26 & 10,0 & * & MHC; & * & * & * & * & $\begin{array}{l}\text { General Ro-Ro: ship to shore } \\
\text { (and vice versa) (1); } \\
\text { Dry bulks: Ship to truck/wagon } \\
\text { (and vice versa) (2); } \\
\text { General Lo-Lo: ship to shore/ } \\
\text { truck/ wagon } \\
\text { (and vice versa) (3); } \\
\text { Containers Lo-Lo: ship to truck/ } \\
\text { wagon } \\
\text { (and vice versa) (2); }\end{array}$ \\
\hline 31 & 9,0 & * & MHC; & * & * & * & * & $\begin{array}{l}\text { General Ro-Ro: ship to shore } \\
\text { (and vice versa) (1); } \\
\text { Dry bulks: Ship to truck (and } \\
\text { vice versa) (1); } \\
\text { General Lo-Lo: ship to shore/ } \\
\text { truck (and vice versa) (2); } \\
\text { Containers Lo-Lo: ship to truck } \\
\text { (and vice versa) (1); }\end{array}$ \\
\hline
\end{tabular}


Based on data systematized in the Table 4, potential values of parameters which determine short sea shipping capability (potential) of the

Port of Bar can be defined (Table 5).

\section{Table 5}

Potential Values of Parameters which Determine the Port of Bar Short Sea Shipping Capability (Potential), from the Aspect of Available Shore Port Machinery

\begin{tabular}{|c|c|c|c|c|c|c|c|c|c|c|c|c|c|c|c|c|c|c|}
\hline Berth & $\mathrm{NPV}$ & $\mathrm{SO} 3$ & $\mathrm{SO} 2$ & $\mathrm{SO} 1$ & 03 & 02 & 01 & 11 & 12 & 13 & 14 & 21 & 22 & 23 & 24 & 25 & 26 & 31 \\
\hline $\mathrm{A}$ & $\mathrm{N}$ & $\mathrm{N}$ & $\mathrm{N}$ & $\mathrm{N}$ & $\mathrm{Y}$ & $\mathrm{Y}$ & $\mathrm{Y}$ & $\mathrm{Y}$ & $\mathrm{Y}$ & $\mathrm{Y}$ & $\mathrm{Y}$ & $\mathrm{Y}$ & $\mathrm{Y}$ & $\mathrm{N}$ & $\mathrm{Y}$ & $\mathrm{Y}$ & $\mathrm{N}$ & $\mathrm{N}$ \\
\hline$(\mathrm{A})_{\mathrm{pot}}$ & & & & & & & & & & & & & & $\mathrm{Y}$ & & & $\mathrm{Y}$ & $\mathrm{Y}$ \\
\hline $\mathrm{N}_{\mathrm{ct}}$ & 1 & 1 & 1 & 1 & 3 & 2 & 2 & 3 & 2 & 2 & 2 & 2 & 2 & 0 & 1 & 1 & 1 & 1 \\
\hline$\left(\mathrm{N}_{\mathrm{ct}}\right)_{\mathrm{pot}}$ & & & & & 4 & 3 & 3 & 4 & 3 & 3 & 3 & 3 & 3 & 3 & 3 & 3 & 4 & 4 \\
\hline $\mathrm{N}_{\mathrm{o}}$ & 1 & 1 & 1 & 1 & 7 & 7 & 7 & 7 & 5 & 5 & 5 & 5 & 5 & 0 & 3 & 3 & 1 & 1 \\
\hline$\left(\mathrm{N}_{\mathrm{o}}\right)_{\mathrm{pot}}$ & & & & & 10 & 10 & 10 & 9 & 8 & 7 & 7 & 7 & 7 & 7 & 7 & 7 & 8 & 5 \\
\hline $\mathrm{N}_{\mathrm{g}}$ & 0 & 0 & 0 & 0 & 3 & 3 & 3 & 1 & 1 & 3 & 1 & 4 & 4 & 0 & 3 & 3 & 0 & 0 \\
\hline$\left(\mathrm{N}_{\mathrm{g}}\right)_{\mathrm{pot}}$ & & & & & 4 & 4 & 4 & 2 & 2 & 4 & 2 & 5 & 5 & 1 & 4 & 4 & 1 & 1 \\
\hline
\end{tabular}

\section{Discussion of the Results}

Results of done analyses clearly confirm existence of direct correlation between the short sea shipping capability (potential) of a port and level of the port machinery flexibility: to a higher level of the port machinery flexibility corresponds a higher short sea shipping capability (potential) of a port.

By the simulation of effects of introducing a mobile harbour crane (as a port machine with optimal level of flexibility, positional and technological) is illustrated a mechanism of influence of port machinery flexibility on parameters which characterize short sea shipping capability (potential) of a port:

- potential availability of the port machinery by berths, $(A)_{p o t}$, is increased - for $16,3 \%$;

- potential number of cargo types which can be handled by berths, $\left(N_{c t}\right)_{p o t}$, is increased, too; increasing rate varies from $33 \%$ (at berths 03) to $300 \%$ (at berths 26 and 31); introducing a mobile harbour crane would enable Lo-Lo handling operations with dry bulks, general cargoes and containers at the berth 23, where regularly only handling operations with ship gears are performed;

- potential number of handling operations which can be realized by berths, $\left(N_{0}\right)_{p o t}$, is increased from $29 \%$ (at berth 11) to $700 \%$ (at berths 26); a mobile harbour crane would enable handling operations, using port machinery, and at berth 23;

- potential number of gangs which can be allocated at a berth/ship, $\left(N_{g}\right)_{p o t}$, is, as well, under positive influence of introducing a flexible mobile harbour crane; it values increased from $25 \%$ (at berths 21 and 22) to 50\% (at berths 11, 12 and 14).

\section{Conclusion}

With results of analyses done in this paper is confirmed starting hypothesis about existence of direct correlation between the 
short sea shipping capability (potential) of a port and level of the port machinery flexibility. Higher level of the port machinery flexibility corresponds to the higher short sea shipping capability (potential) of a port.

Short sea shipping capability (potential) of a port, from the aspect of port machinery, can be adequately measured by following four parameters: availability of port machinery (by berths), $A$; number of cargo types which can be handled (by berths), $N_{c}$; number of handling operations which can be realized (by berths), $N_{o}$; number of gangs which can be allocated at a berth/ship, $N_{g}$.

\section{References}

Beresdorf, A.K.C.; Gardner, B.M.; Pettit, S.J.; Naniopoulos, S.; Wooldridge, C.F. 2004. UNCTAD and WORKPORT models of port development: evolution or revolution, Maritime Policy and Management. DOI: http://dx.doi.org/10.1080/0308883042000205061 , 31(2): 93-107.

Cambridge Systematics, Inc. Short-Sea and Coastal Shipping Options Study, Final Report. Available from Internet: <http://www.i95coalition.org/>.

De la Lastra, C.M. 2004. EU policy to Promote Short Sea Shipping, Transport Forum (Brussels) Maritime Transport Working Group. In Proceedings of the Ports and Short Sea Shipping $3 r d$ meeting.

Delovic, D. 2014. An Analysis of bases for defining level of the port machinery flexibility in a multipurpose seaport. In Proceedings of the International Conference on Traffic and Transport Engineering, Belgrade, 51-59.
Dobner, M.; Rijsenbrij, J. 1999. Equipment Selection and Utilization - Key Factors for Smaller Terminals. In Proceedings of AAPA Facilities Engineering Seminar.

Documentation of the Port of Bar. 2014.

Dundovic, C. 2005. Port Machinery of Cyclic Transport (in Croatian), Faculty of Maritime Studies Rijeka, Croatia.

European Commission. Available from Internet: <www. ec.europa.eu/transport/maritime/sss/>.

Paixao Casaca, A.C.; Marlow, P.B. 2005. The competitiveness of short sea shipping in multimodal logistics supply chains: service attributes, Maritime Policy and Management. DOI: http://dx.doi. org/10.1080/03088830500301469, 32(4): 363-382.

Papadimitriou, S. 2011. Short Sea Shipping in Europe: Experience and Prospects. European Conference of Ministers of transport. Available from Internet: <http:// www.internationaltransportforum.org/>. 9-16.

Report adopted by the ECMT Ministers of Transport at the Council of Ministers. 2011. Short Sea Shipping: An Alternative to European Inland Transport or a Complementary Mode. Conference of Ministers of transport. Available from Internet: <http://www. internationaltransportforum.org/>. 37-70.

Roach, T. 1987. Operating and Maintenance Features of Container Handling System. The World Bank.

Sanchez, R.J.; Wilmsmeier, G. 2005. Short-sea shipping potentials in Central America to bridge infrastructural gaps, Maritime Policy and Management. DOI: http://dx.doi. org/10.1080/03088830500139679, 32(3): 227-244.

Short Sea Promotion Centre. Available from Internet: $<$ www.shortsea.fr/short-sea-definition $>$. 
Short Sea Shipping in Europe. Available from Internet: $<$ www.developpement-durable.gouv.fr/>.

Styhre, L.; Roso, V.; Bergqvist, R.; Woxenius, J.; Lumsden, K. 2014. Development of the Short Sea Shuttle Concept. University of Gothenburg, Swedish Environmental Research Institute, Chalmers University of Technology. Available from Internet: <http://www. ivl.se/>.

Terex Corporate. Available from Internet: <www.elit. terex.com $>$.

The Development of Short Sea Shipping in Europe: A Dynamic Alternative in a Sustainable Transport Chain. Available from Internet: <http://ec.europa.eu/>.
University of Michigan, Department of Naval Architecture and Marine Engineering. The Environmental \& Economic Benefits of Short Sea Shipping by 'Container-On-Barge'. Available from Internet: <http://towmasters.files.wordpress.com/>.

Zachcial, M. 2011. Short Sea Shipping and Intermodal Transport, European Conference of Ministers of Transport. Available from Internet: <http://www. internationaltransportforum.org/>. 21-24.

\section{jitte 308}

